\title{
TP53 codon 72 polymorphism in 12 populations of insular Southeast Asia and Oceania
}

\author{
Taeko Kashima · Kumiko Makino • \\ Augustinua Soemantri · Takafumi Ishida
}

Received: 15 April 2007/Accepted: 1 June 2007/Published online: 3 July 2007

(C) The Japan Society of Human Genetics and Springer 2007

\begin{abstract}
Distribution of a single nucleotide polymorphism in the TP53 codon 72 (Arg/Pro) was studied in Southeast Asia and Oceania where information about this polymorphism was lacking. A polymerase chain reaction restriction fragment length polymorphism method was employed to genotype a total of 733 subjects from 12 populations in insular Southeast Asia and Oceania. These populations have been classified as either an Austronesianspeaking group or Papuan-speaking group. The p53Arg frequencies ranged from 0.06 in the Seramese to 0.62 in the Kahayan with an average frequency of 0.38 . No significant correlation between the p53Arg frequency and latitude was observed in the 12 populations tested $(P>0.05)$, whereas a significant correlation was obtained for the relationship between frequency and longitude among 9 Austronesian or the whole 12 populations tested $(P<0.01)$. A longitudinal cline of the p53Arg frequencies may reflect the history of the Austronesian's migration and local admixture with indigenous Papuan speakers who had probably harbored low p53Arg frequencies.
\end{abstract}

Keywords TP53 $\cdot$ Codon 72 polymorphism . Southeast Asia · Oceania · Austronesian · Papuan

T. Kashima $\cdot$ K. Makino $\cdot$ T. Ishida $(\square)$

Unit of Human Biology and Genetics,

Department of Biological Sciences,

Graduate School of Science,

University of Tokyo, 7-3-1 Hongo,

Bunkyo-ku, Tokyo 113-0033, Japan

e-mail: tishida@biol.s.u-tokyo.ac.jp

A. Soemantri

Department of Child Health, Faculty of Medicine,

Diponegoro University, Semarang, Indonesia

\section{Introduction}

The TP53 is an important tumor suppressor gene in humans and animals (Levine et al. 2006). TP53 protein (p53) is a multifunctional protein that plays central roles in cellular responses to DNA damage, cellular senescence and apoptosis to maintain genomic stability of a cell. Despite the conservative amino acid sequence of p53 throughout many animal species (D’Erchia 1999), TP53 harbors a single nucleotide polymorphism at codon 72 in exon 4 that results in the presence of either a proline (p53Pro) or an arginine (p53Arg) residue. From the studies in vitro and in vivo (Bergamaschi et al. 2006; Dumont et al. 2003; Marin et al. 2000; Matlashewski et al. 1987; Storey et al. 1998; Thomas et al. 1999), biologically and biochemically different properties between the two p53 variants would be deduced as follows: p53Pro tends to ensure cell survival by inducing G1 arrest and DNA repair, whereas p53Arg induces apoptosis through mitochondrial pathways. It is thus indicated that both allelic variants act as the guardian of the cell in their own modes.

Allelic distribution of TP53 codon 72 varies in many populations (Beckman et al. 1994; Bereir et al. 2003), and moreover, case-control studies on various cancers have proposed significant and non-significant associations between cancer susceptibility and either of the allelic variants (Mabrouk et al. 2003; Siddique et al. 2005; Tommiska et al. 2005; Tiwawech et al. 2003). To imply the universal distribution of TP53 codon 72 polymorphism, the presence of some selective pressure such as ultraviolet (UV) light intensity on the maintenance of the polymorphic status was postulated (Beckman et al. 1994); however, this could not be generalized (Bereir et al. 2003; Gaspar et al. 2002; Khaliq et al. 2000). Although more than 250 reports on TP53 codon 72 
polymorphism have been published so far, various world populations such as in Southeast Asia and Oceania are still left behind for the screening, which limits the search for a possible implication on this common polymorphism.

We have studied TP53 codon 72 polymorphism and cancer susceptibility in several cancers in Southeast Asia (Tiwawech et al. 2003; Kietthubthew et al. 2003; Settheetham-Ishida et al. 2004, 2005). In this study, we have screened for the TP53 codon 72 polymorphism among ethnic groups of Southeast Asia and Oceania to fill in the map of the distribution of this polymorphism.

\section{Materials and method}

\section{Subjects}

A total of 733 individuals from 12 populations in insular Southeast Asia and Oceania were the subjects of this study (Table 1). They were from unrelated individuals so as to represent populations. People in these areas have been classified into two groups, the Austronesian-speaking group and Papuan-speaking group. From the Austronesianspeaking group, the following nine populations were studied: the Kahayan $(n=41)$, the Berau $(n=68)$, the Madurian $(n=76)$, the Bugis $(n=53)$, the Toraja $(n=91)$, the Timorese $(n=102)$, the Seramese $(n=48)$, the Floresian $(n=85)$ and Austronesian speaking individ-

Table 1 Genotype distribution of the TP53 codon 72 and p53Arg allele frequency in each group of insular Southeast Asia and Oceania

\begin{tabular}{lllll}
\hline Population & Number & p53 genotype & $\begin{array}{l}\text { Freq. of } \\
\text { p53Arg }\end{array}$ \\
\cline { 2 - 3 } & Arg/Arg Pro/Arg Pro/Pro &
\end{tabular}

\begin{tabular}{|c|c|c|c|c|c|}
\hline \multicolumn{6}{|c|}{ Austronesian speaking } \\
\hline Kahayan & 41 & 14 & 23 & 4 & 0.62 \\
\hline Berau & 68 & 11 & 35 & 22 & 0.42 \\
\hline Madurian & 76 & 23 & 33 & 20 & 0.52 \\
\hline Bugis & 53 & 17 & 24 & 12 & 0.55 \\
\hline Traja & 91 & 19 & 43 & 29 & 0.45 \\
\hline Timorese & 102 & 18 & 38 & 46 & 0.36 \\
\hline Seramese & 48 & 0 & 6 & 42 & 0.06 \\
\hline Floresian & 85 & 8 & 32 & 45 & 0.28 \\
\hline $\begin{array}{l}\text { in New Guinea } \\
\text { Island }\end{array}$ & 35 & 0 & 7 & 28 & 0.10 \\
\hline \multicolumn{6}{|l|}{ Papuan speaking } \\
\hline Dani & 70 & 10 & 23 & 37 & 0.31 \\
\hline Ekari & 49 & 11 & 18 & 20 & 0.41 \\
\hline Asmat & 15 & 0 & 7 & 8 & 0.23 \\
\hline Total & 733 & 131 & 289 & 313 & 0.38 \\
\hline
\end{tabular}

uals in New Guinea Island $(n=35)$. Three populations studied in the Papuan-speaking group in New Guinea Island were the Dani $(n=70)$, the Ekari $(n=49)$ and the Asmat $(n=15)$, who have been relatively isolated until recently.

We used genomic DNA obtained from peripheral blood lymphocytes or from immortalized cell lines with EpsteinBarr virus in the following analysis. Anonymous Seramese samples were kindly provided by Dr. M. Hirai. This study was approved by the institutional Ethics Committee, and informed consent had been obtained from the subjects.

\section{Genotyping}

The DNA samples were subjected to a polymerase chain reaction-restriction fragment length polymorphism (PCRRFLP) assay for genotyping TP53 codon 72 polymorphism. PCR amplification was performed with a primer set, 5'-CCCGGACGACGATATTGAACA-3' and 5'-AGAAGCCCAGACGGAAAC- $3^{\prime}$. An initial denaturation at $95^{\circ} \mathrm{C}$ for 9 min was followed by 40 cycles of denaturation at $94^{\circ} \mathrm{C}$ for $30 \mathrm{~s}$, annealing at $61^{\circ} \mathrm{C}$ for $30 \mathrm{~s}$ and extension at $72^{\circ} \mathrm{C}$ for $30 \mathrm{~s}$, with a final extension at $72^{\circ} \mathrm{C}$ for $4 \mathrm{~min}$. PCR products (203 bp) were digested at $60^{\circ} \mathrm{C}$ for $3 \mathrm{~h}$ with BstUI (NEB). Presence of the restriction site (CGCG) in the PCR products corresponds to the p53Arg showing two fragments with 125 and $72 \mathrm{bp}$, otherwise uncut (p53Pro). These fragments were visualized on $3 \%$ agarose gel electrophoresis with ethidium bromide staining.

Statistical analysis

Deviation from the Hardy-Weinberg's equilibrium was tested by the $\chi^{2}$ and the exact tests. Correlation between latitude or longitude and the 72Arg frequency was tested by Spearman's rank correlation test. To compare the p53Arg frequencies between the Austronesian-speaking group and Papuan-speaking group, the Mann-Whitney $U$ test was employed. A $P$ value less than 0.05 was considered to be significant.

\section{Results and discussion}

Genotype distribution and the p53Arg frequency in each group are presented in Table 1, and the frequency of the p53Arg in each population is mapped in Fig. 1. The p53Arg frequencies ranged from 0.06 in the Seramese to 0.62 in the Kahayan, with an average frequency of 0.38 , and the p53Arg frequency was not significantly different between the Austronesian-speaking group and Papuanspeaking group $(P>0.05)$. Distribution of the genotype in each population was in Hardy-Weinberg equilibrium 
Fig. 1 Location and allelic distribution of the TP53 codon 72 polymorphism in each Southeast Asia and Oceania. Pies with black and gray segments are the Austronesian and Papuan group, respectively. Size of the pie indicates number of subjects population studied in insular

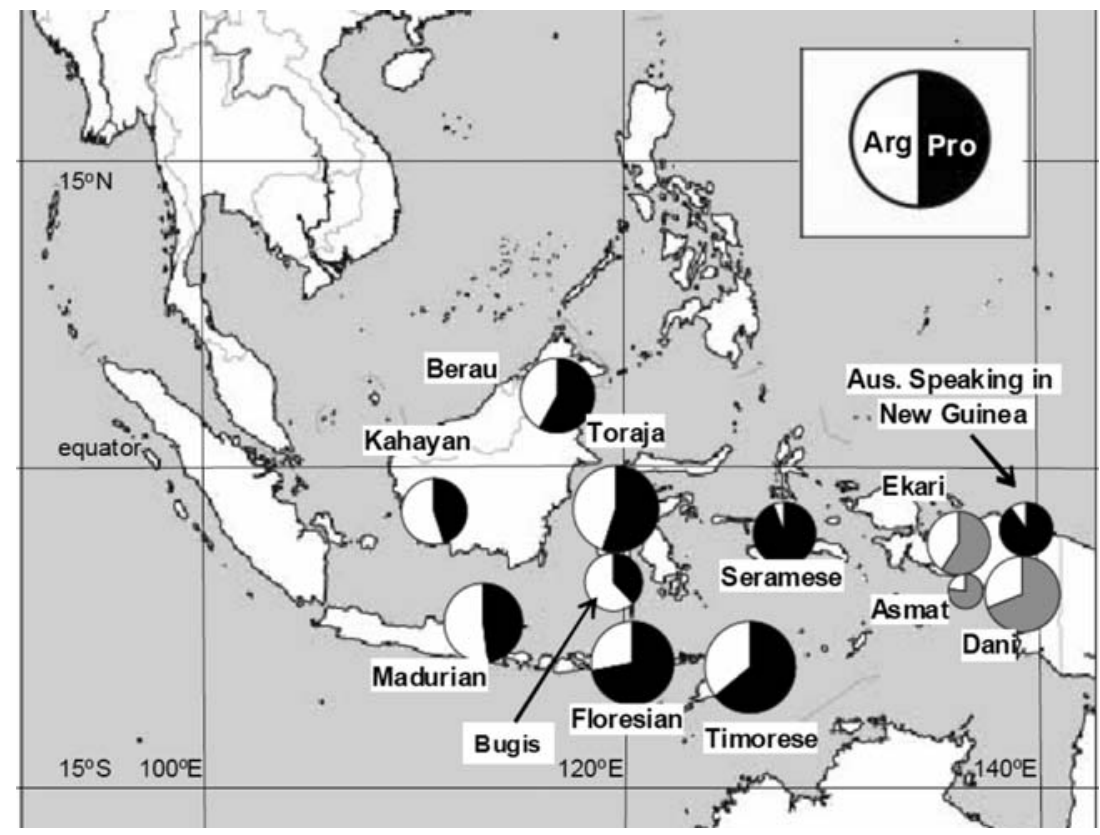

except for the Timorese $(P<0.05)$. An overall genotype distribution between the Austronesian-speaking group and Papuan-speaking group was not significantly different regardless of the presence of Timorese $(P>0.05)$.

No significant correlation between the p53Arg allele frequency and latitude was observed in the 12 populations tested $(P>0.05)$; however, a significant correlation was obtained for the relationship between the frequency and the longitude among 9 Austronesian or the whole 12 populations tested $(P<0.01)$. These results were confirmed when we employed multiple linear regression analyses. To interpret the allele frequencies among these groups, historical backgrounds of the populations should be taken into consideration (Fig. 2).

The ancestors of the Austronesian-speaking people started migration from South China about 6,000 years ago (Bellwood 1989), then, having moved from island to island with canoes, they finally settled in Southeast Asia and Oceania where the ancestral Papuan-speakers inhabited. Genetic drift and/or bottleneck most likely shaped their genetic composition during their peopling, and then admixture with the indigenous Papuan speakers took place in insular Southeast Asia and Oceania. In line with these genetic events, allelic distribution of TP53 codon 72 in the region may reach the present form. A longitudinal cline of the p53Arg (higher in the west and lower in the east) may be the result of Austronesian's migration and local admixture with indigenous Papuan speakers who had probably harbored low p53Arg frequencies. This does not exclude possible contributions of genetic events such as genetic drift and bottleneck that may alter the allele frequency.

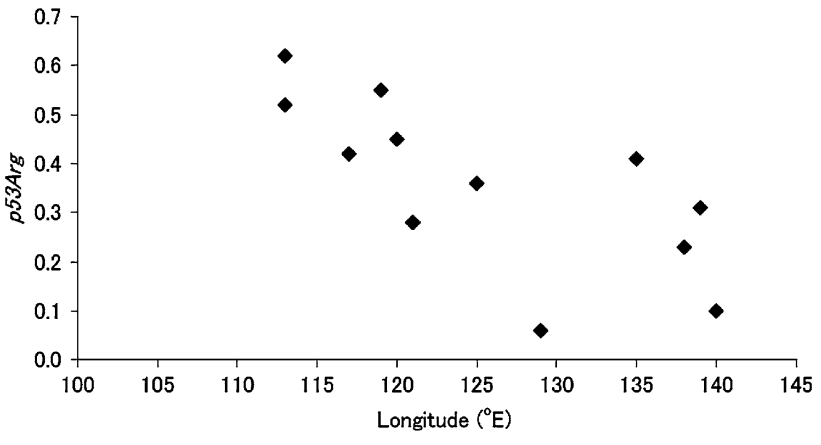

Fig. 2 Longitudinal distribution of p53Arg frequency

A relatively low p53Arg frequency (average frequency of 0.38) corresponded to the conclusion of Beckman et al. (1994) that frequencies of p53Arg are low in low latitudes with an altitudinal cline in the frequencies. They also suggested that this altitudinal cline should be an outcome of natural selection and speculated that adaptation to UV light intensity might be the driving force for the formation of the cline. A typical human trait related to the UV light intensity or the latitude is skin pigmentation. Quite recently a direct participation of p53 in the skin pigmentation has been demonstrated (Cui et al. 2007), and this finding may lead to a possible link between the latitude and p53 polymorphism if it ever exists. In the present study, we could not find a cline such as in the regional surveys in Sudan and Pakistan (Bereir et al. 2003; Khaliq et al. 2000). It is of course premature to draw a conclusion at this moment because the subjected populations were located in a small range of altitude $\left(2^{\circ} \mathrm{N}-9^{\circ} \mathrm{S}\right)$. To shed light on the cryptic background responsible for the ubiquitous presence as well 
as different frequency of the TP53 polymorphism, more extensive screenings for the polymorphism in other Asian and Pacific populations who have relatively close genealogic relationships are awaited.

Acknowledgments This work was partly supported by the grants from the Ministry of Education, Culture, Sports, Science and Technology, Japan and Japan Society for the Promotion of Science.

\section{References}

Beckman G, Birgander R, Sjalander A, Saha N, Holmberg PA, Kivela A, Beckman L (1994) Is p53 polymorphism maintained by natural selection? Hum Hered 44:266-270

Bellwood P (1989) The colonization of the Pacific: some current hypotheses. In: Hill AVS, Serjeantson SW (eds) The colonization of the Pacific: a genetic trail. Oxford University Press, New York, pp 1-59

Bereir RE, Mohamed HS, Seielstad M, El Hassani AM, Khalil EA, Peacock CS, Blackwell JM, Ibrahim ME (2003) Allele frequency and genotype distribution of polymorphisms within diseaserelated genes is influenced by ethnic population sub-structuring in Sudan. Genetica 119:57-63

Bergamaschi D, Samuels Y, Sullivan A, Zvelebil M, Breyssens H, Bisso A, Del Sal G, Syed N, Smith P, Gasco M, Crook T, Lu X (2006) iASPP preferentially binds $p 53$ proline-rich region and modulates apoptotic function of codon 72-polymorphic p53. Nat Genet 38:1133-1141

Cui R, Widlund HR, Feige E, Lin JY, Wilensky DL, Igras VE, D'Orazio J, Fung CY, Schanbacher CF, Granter SR, Fisher DE (2007) Central role of p53 in the suntan response and pathologic hyperpigmentation. Cell 128:853-864

D'Erchia A M, Pesole G, Tullo A, Saccone C, Sbisa E (1999) Guinea pig p53 mRNA: identification of new elements in coding and untranslated regions and their functional and evolutionary implications. Genomics 58:50-64

Dumont P, Leu JI, Della Pietra AC 3rd, George DL, Murphy M (2003) The codon 72 polymorphic variants of $\mathrm{p} 53$ have markedly different apoptotic potential. Nat Genet 33:357-365

Gaspar PA, Hutz MH, Salzano FM, Hill K, Hurtado AM, Petzl-Erler ML, Tsuneto LT, Weimer TA (2002) Polymorphisms of CYP1a1, CYP2e1, GSTM1, GSTT1, and TP53 genes in Amerindians. Am J Phys Anthropol 119:249-256

Khaliq S, Hameed A, Khaliq T, Ayub Q, Qamar R, Mohyuddin A, Mazhar K, Qasim-Mehdi S (2000) P53 mutations, polymorphisms, and haplotypes in Pakistani ethnic groups and breast cancer patients. Genet Test 4:23-29
Kietthubthew S, Sriplung H, Au WW, Ishida T (2003) The p53 codon 72 polymorphism and risk of oral cancer in Southern Thailand. Asian Pac J Cancer Prev 4:209-214

Levine AJ, Hu W, Feng Z (2006) The P53 pathway: what questions remain to be explored? Cell Death Differ 13:1027-1036

Mabrouk I, Baccouche S, El-Abed R, Mokdad-Gargouri R, Mosbah A, Said S, Daoud J, Frikha M, Jlidi R, Gargouri A (2003) No evidence of correlation between p53 codon 72 polymorphism and risk of bladder or breast carcinoma in Tunisian patients. Ann N Y Acad Sci 1010:764-70

Marin MC, Jost CA, Brooks LA, Irwin MS, O’Nions J, Tidy JA, James N, McGregor JM, Harwood CA, Yulug IG, Vousden KH, Allday MJ, Gusterson B, Ikawa S, Hinds PW, Crook T, Kaelin WG Jr (2000) A common polymorphism acts as an intragenic modifier of mutant p53 behaviour. Nat Genet 25:47-54

Matlashewski GJ, Tuck S, Pim D, Lamb P, Schneider J, Crawford LV (1987) Primary structure polymorphism at amino acid residue 72 of human p53. Mol Cell Biol 7:961-963

Settheetham-Ishida W, Singto Y, Yuenyao P, Tassaneeyakul W, Kanjanavirojkul N, Ishida T (2004) Contribution of epigenetic risk factors but not p53 codon 72 polymorphism to the development of cervical cancer in Northeastern Thailand. Cancer Lett 210:205-11

Settheetham-Ishida W, Kanjanavirojkul N, Kularbkaew C, Ishida T (2005) Human papillomavirus genotypes and the p53 codon 72 polymorphism in cervical cancer of Northeastern Thailand. Microbiol Immunol 49:417-421

Siddique MM, Balram C, Fiszer-Maliszewska L, Aggarwal A, Tan A, Tan P, Soo KC, Sabapathy K (2005) Evidence for selective expression of the p53 codon 72 polymorphs: implications in cancer development. Cancer Epidemiol Biomarkers Prev $14: 2245-52$

Storey A, Thomas M, Kalita A, Harwood C, Gardiol D, Mantovani F, Breuer J, Leigh IM, Matlashewski G, Banks L (1998) Role of a p53 polymorphism in the development of human papillomavirusassociated cancer. Nature 393:229-234

Thomas M, Pim D, Banks L (1999) The role of the E6-p53 interaction in the molecular pathogenesis of HPV. Oncogene 18:7690-7700

Tiwawech D, Srivatanakul P, Karaluk A, Ishida T (2003) The p53 codon 72 polymorphism in Thai nasopharyngeal carcinoma. Cancer Lett 198:69-75

Tommiska J, Eerola H, Heinonen M, Salonen L, Kaare M, Tallila J, Ristimaki A, von Smitten K, Aittomaki K, Heikkila P, Blomqvist C, Nevanlinna H (2005) Breast cancer patients with p53 Pro72 homozygous genotype have a poorer survival. Clin Cancer Res 11:5098-5103 